\title{
An analysis of the demand for business aircraft among the corporate sector in South Africa
}

\begin{tabular}{|c|c|}
\hline $\begin{array}{l}\text { Authors: } \\
\text { Mpho J. Mab } \\
\text { Ngoasheng J. } \\
\text { Bernard Tave } \\
\text { Jacobus Walt } \\
\text { Martie A. Me } \\
\text { Elana Swanep }\end{array}$ & $\begin{array}{l}\operatorname{tja}^{1} \text { (1) } \\
\text { Mampana }^{2} \\
\operatorname{gwa}^{3} \text { (1) } \\
\mathrm{rs}^{3} \text { (1) } \\
\operatorname{arns}^{2} \text { (1) } \\
\text { oel }^{1} \text { (D) }\end{array}$ \\
\hline $\begin{array}{l}\text { Affiliations: } \\
{ }^{1} \text { Department } \\
\text { Management } \\
\text { Johannesbur } \\
\text { South Africa }\end{array}$ & $\begin{array}{l}\text { of Business } \\
\text { University of } \\
\text {, Johannesburg, }\end{array}$ \\
\hline $\begin{array}{l}{ }^{2} \text { Department } \\
\text { and Knowled } \\
\text { Management } \\
\text { Johannesburg } \\
\text { South Africa }\end{array}$ & $\begin{array}{l}\text { of Information } \\
\text { University of } \\
\text {, Johannesburg, }\end{array}$ \\
\hline $\begin{array}{l}{ }^{3} \text { Department } \\
\text { and Supply } \mathrm{Cl} \\
\text { Management } \\
\text { Johannesburg } \\
\text { South Africa }\end{array}$ & $\begin{array}{l}\text { of Transport } \\
\text { Iain } \\
\text { University of } \\
\text {, Johannesburg, }\end{array}$ \\
\hline $\begin{array}{l}\text { Correspondin } \\
\text { Jacobus Walt } \\
\text { jwalters@uj.a }\end{array}$ & $\begin{array}{l}\text { g author: } \\
\text { ers, } \\
\text { c.za }\end{array}$ \\
\hline $\begin{array}{l}\text { Dates: } \\
\text { Received: } 28 \\
\text { Accepted: } 03 \\
\text { Published: } 24\end{array}$ & $\begin{array}{l}\text { an. } 2019 \\
\text { Apr. } 2019 \\
\text { June } 2019\end{array}$ \\
\hline $\begin{array}{l}\text { How to cite th } \\
\text { Mabotja, M.J., } \\
\text { Tavengwa, B., } \\
\text { Mearns, M.A. } \\
\text { 2019, 'An ana } \\
\text { demand for b } \\
\text { among the co } \\
\text { in South Afric } \\
\text { Transport ano } \\
\text { Management } \\
\text { https://doi.or } \\
\text { jtscm.v13i0.4 }\end{array}$ & $\begin{array}{l}\text { is article: } \\
\text { Mampana, N.J., } \\
\text { Walters, J., } \\
\text { \& Swanepoel, E., } \\
\text { lysis of the } \\
\text { usiness aircraft } \\
\text { rporate sector } \\
\text { a', Journal of } \\
\text { Supply Chain } \\
13(0) \text {, a441. } \\
\text { g/10.4102/ } \\
41\end{array}$ \\
\hline $\begin{array}{l}\text { Copyright: } \\
\text { (C) 2019. The } \\
\text { Licensee: AOS } \\
\text { is licensed un } \\
\text { Creative Com } \\
\text { Attribution Lic }\end{array}$ & $\begin{array}{l}\text { Authors. } \\
\text { IS. This work } \\
\text { der the } \\
\text { mons } \\
\text { :ense. }\end{array}$ \\
\hline Read online: & \\
\hline 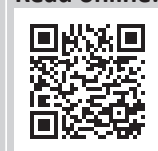 & $\begin{array}{l}\text { Scan this QR } \\
\text { code with your } \\
\text { smart phone or } \\
\text { mobile device } \\
\text { to read online. }\end{array}$ \\
\hline
\end{tabular}

Background: Business aircraft fulfil a major need in providing access and mobility solutions not generally offered by scheduled commercial aircraft. These aircraft often make use of secondary airports in outlying areas thus encouraging economic development. Business aviation is, in general, growing throughout the world and also in some African countries, but appears to be subdued in South Africa. The purpose of this research project was to determine the demand characteristics for business aviation aircraft in South Africa.

Objectives: The primary research objective was to determine the demand for business aircraft in South Africa, as well as the nature and characteristics of the users and non-users of business aircraft among the top 100 companies listed on the Johannesburg Stock Exchange (JSE).

Method: A pragmatic research philosophy guided an exploratory sequential mixed methods research design. Findings from face-to-face interviews with aviation experts were utilised to develop the research questionnaire distributed to the top 100 JSE-listed companies.

Results: The potential future growth for the business aircraft market is most likely to come from existing users, with marginal growth from new entrants in the market. Perceived costs are major deterrents to the utilisation of business aircraft.

Conclusion: The research provides market intelligence necessary to guide business aviation companies to efficiently service or expand the market for business aircraft in South Africa, contributing to the existing knowledge in air transport.

Keywords: business aircraft; business aviation; operational costs; users; non-users; demand; market; South Africa; ownership model.

\section{Introduction}

The business aircraft market caters for companies and institutions of various sizes that utilise a range of aircraft over varying distances for services ranging from humanitarian relief to business air travel and tourism. Organisations tend to choose business aircraft over (or in addition to) scheduled airline services for reasons such as flight-time flexibility, taxation benefits and global reach. The International Civil Aviation Organisation (ICAO) (1998:2) defines business aviation as that part of the aviation industry that utilises general aviation aircraft for business purposes.

Since the early 1990s, the global business aviation market recorded a healthy growth rate, consisting of a fleet of 6056 business aircraft by 2016 (GAMA 2016:40). However, the growth rate in the South African market has been sluggish, lagging behind the growth rates of other business aircraft markets, such as Nigeria (AfBAA 2015). Leading aircraft suppliers and related stakeholders have expressed concern over this slower than expected growth rate in South Africa. In addition, a 2009 Standard and Poor (S\&P) study of 500 companies found that financial performance in organisations is positively influenced using business aircraft (NEXA 2009:3). Since 2009, a more recent study has not yet been conducted.

Nevertheless, the potential for the business aircraft market in Africa is highlighted by Bombardier (2016:34), a supplier of business aircraft, pointing out that for the 10-year period from 2016 to 2026, a 4.4\% compound annual growth rate (CAGR) is forecast for Africa.

The nature, characteristics and the extent of the business aircraft usage in South Africa have not yet been researched. Business aircraft-related publications emanate from international and local organisations active in the business aircraft industry, publishing industry data such as the General Aviation Manufacturers Association (GAMA) (2016) and the Civil Aviation Authority (CAA) (2017). The latter provides data on the number of business aircraft registered in South Africa. 


\section{Research problem statement}

Business aircraft companies operating in First World regions, such as North America and Europe, have access to information regarding the needs, nature and characteristics of the consumers of their products, as is evident from sources used in the study (such as AfBAA 2015; Bombardier 2016; GAMA 2016; NEXA 2009). In these regions, several comprehensive industry and statistical reports on business aviation are published regularly to enable business aviation companies to make informed business decisions regarding the users of their business aircraft.

However, for Africa, and South Africa in particular, very limited business aviation market intelligence is available, contained in disparate sources. From an industry and a user's perspective, it lacks comprehensiveness regarding the nature, characteristics and the extent of business aircraft usage in the region.

\section{Research objective}

The primary research objective of this study was to determine the extent of and drivers of the demand for business aircraft in South Africa, as well as the nature and characteristics of the users and potential users of business aircraft among the top 100 Johannesburg Stock Exchange (JSE)-listed companies.

\section{Literature overview}

\section{Structure of the global business aviation industry}

The global business aviation industry is structured in terms of purpose, aircraft types, ownership models and manufacturers. There are three purpose-distinguished categories of business aircraft, namely commercial, corporate and owner-operated aircraft (ICAO 1998:2). Business aircraft can be further classified into four types according to their propulsion system, namely helicopter, turboprop, piston and jet system (SustainAvia 2012:12). As Andersen, McNay and Peterson (2012) have explained, business aircraft can further be classified by maximum take-off weight (MTOW) of the aircraft into four classes: very light business aircraft, light business aircraft, medium business aircraft and large business aircraft. The seven major manufacturers of business aircraft are located in the United States, Canada, France and Brazil, namely Cessna, Beechcraft, Gulfstream, Learjet, Bombardier, Dassault and Embraer (Andersen et al. 2012).

\section{Business aviation ownership models}

Organisations and individuals can own or gain access to a business aircraft through models such as full ownership, fractional ownership, joint ownership, chartering and flight cards. Full ownership means the buyer fully owns the aircraft (Deloitte 2014). In fractional aircraft ownership, the buyer purchases a share of the aircraft, which equates to a certain number of flying hours per year (Deloitte 2014). In joint ownership, a contractual agreement is signed between multiple private owners to share the operational costs and ownership of an aircraft (Deloitte 2014). Chartering is defined as a model in which an aircraft is provided to a client by a charter company and paid for on a flight-by-flight basis (Deloitte 2014). Deloitte (2014) explains flight cards as an ownership model in which aircraft users acquire time (flight hours) for aircraft usage, without the commitment of ownership.

\section{Characteristics of the international and African business aircraft markets}

The market for business aircraft can be categorised into distinct regions by geographical area. The regions are North America, Latin America, Europe, Asia-Pacific, the Middle East and Africa (GAMA 2016). The global market is dominated by the North American and European regions, which account for over $80 \%$ of the world's business aircraft fleet (GAMA 2016:12). The third biggest market is the AsiaPacific region, which includes China, followed by Latin America and the Middle East and Africa (GAMA 2016).

Even though the African business aircraft market is the smallest, it is forecasted to show a steady growth into the future. The regional fleet has doubled in size in the 10 years to 2015 and is expected to experience a CAGR of $3.2 \%$ by 2025 (Bombardier 2016:34).

The African business aircraft fleet comprised of 6941 aircraft, of which $6056(87 \%)$ are registered in South Africa (AfBAA 2015:23). The second and third largest fleets are in Kenya and Nigeria, respectively (AfBAA 2015:23). Even though the South African market is still the largest, between 2008 and 2014 it grew at a mere 2\% annually (GAMA 2016:40), while Nigeria was growing at a rate of $35 \%$ annually and had multiplied in size six times from 2007 to 2014 (AfBAA 2015:23).

\section{Business aviation and the economy}

A growing economy results in an increase in economic activity which leads to an increase in the demand for transportation in the form of business aviation (Bombardier 2016). However, an economy in decline will impact negatively on the demand and supply of business aviation (ICAO 1998). Therefore, the economic slowdown and recession in Nigeria (2.7\%, IMF 2017:18) and South Africa (1.3\%, Statistics South Africa 2017:8), the two countries that economically dominate the sub-Saharan Africa region, could result in a decrease in the demand for business aircraft in the region. The International Monetary Fund (IMF) (2017:5) forecasted growth rates for South Africa of $0.9 \%$ for 2018 and $0.9 \%$ for 2019, and the demand for business aircraft could deteriorate further.

Despite the economic downturn, the number of High Net Worth Individuals (HNWI) and Ultra-High Net Worth Individuals (UHNWI) in Africa had increased in 2017 (The World Wealth Report 2018:77). The World Wealth Report has forecast that the number of African HNWI and UHNWI will 
grow at a rate of $36 \%$ and $34 \%$, respectively, by 2026 . It is likely that a higher number of wealthy individuals would contribute to an increase in the demand for business aircraft in the region.

\section{Market dynamics for business aviation}

In South Africa, several factors drive the demand for aircraft, namely an excellent aviation infrastructure, a good aviation safety record, very high compliance with international aviation standards, being a gateway to Africa and globalisation of trade (AfBAA 2015; CAA 2017).

According to Harris (2009:22), the four primary reasons why organisations use business aircraft are to support schedules not met by scheduled airlines, to access locations scheduled airlines do not service, for industrial or personal safety reasons and to connect with scheduled airline flights. These four primary reasons are still valid today. Two other reasons are that it is more cost-effective to use business aircraft when flying multiple people for business purposes than to use scheduled airlines and that a business aircraft is an economic alternative to commercial travel.

However, on the African continent some negative perceptions about the utilisation of business aircraft exist. According to AfBAA (2015), the four main perceptions are that a business aircraft is an unnecessary luxury, business air travel is dangerous, business aircraft finance is inaccessible and there is a lack of maintenance and technical after-sales support. To understand the slower than expected growth rate of business aviation in South Africa, it was necessary to analyse the underlying perceptions.

\section{Ethical considerations}

The research project was undertaken with Ethical clearance provided by the University of Johannesburg.

\section{Research strategy \\ Research approach}

A pragmatic research philosophy guided the cross-sectional exploratory sequential mixed methods research design, which consisted of two phases. The first qualitative phase focused on the gathering of rich data through in-depth faceto-face interviews with four business aviation experts, guided by an interview schedule. The findings from these interviews informed the development of the structured research questionnaire distributed as the second quantitative phase, conducted as an electronically administered survey to the top 100 JSE-listed companies. To supplement responses, telephonic and face-to-face interviews were conducted with respondents.

\section{Participants and respondents}

The four business aviation experts for the qualitative phase were purposively selected to represent critical elements of the value chain of the business aircraft industry, such as business aircraft sales and marketing and business aircraft maintenance. The target population for the quantitative phase included the top 100 companies on the JSE, by market capitalisation. All 100 companies were included and 30 responded. These respondents had various designations in the respective organisations but were all responsible for decisions relating to business aircraft. However, not all 100 companies were eligible as some (five) are mere holding companies and some (eight) were unreachable. The active response rate is calculated as follows:

Active response rate $=$ Total number of responses $/$ ([Total number in sample] [Ineligible + unreachable]) $=30 /(100-[5+8])=35 \%$

According to Saunders, Lewis and Thornhill (2012:221), a response rate of approximately $35 \%$ is acceptable for academic studies involving top management or the representatives of organisations.

\section{Measuring instrument}

The questionnaire consisted of four sections: firmographic information; business aircraft users' extent of demand, their nature, characteristics and requirements; characteristics of the travel activities of both users and non-users; and drivers of potential demand for business aircraft by non-users.

\section{Treatment of data}

Qualitative data underwent thematic analyses, while the survey elicited 30 responses (11 business aviation users and 19 non-users), analysed using descriptive statistics.

\section{Results: First phase}

\section{Key concerns and drivers in the business aircraft industry}

The following seven themes relating to the business aircraft industry emerged from the interviews with the experts. Cost and regulatory issues seemed to be the most critical concerns for the utilisation of business aircraft.

\section{Theme: Cost issues}

- An aircraft is a costly mode of transport. The key costs which were cited by the experts were purchasing, maintenance, operating, management, staffing and compliance costs.

\section{Theme: Regulatory issues}

- The regulatory environment in South Africa was perceived as an inhibitor to growth. Regulations were found to be cumbersome, complex, costly, long-winded and that it favoured punitive over incentivising measures. Regulators were also found to be staffed by employees who lacked aviation knowledge. 


\section{Theme: Stakeholder perceptions}

- Stakeholders (unions, board of directors, staff, members of the media and other internal and external stakeholders) generally view business aircraft as unnecessary luxury 'toys' abused by management to the detriment of the company.

\section{Theme: Economic determinants}

- A business aircraft is costly to operate during economic downturns. However, this is countered by its ability to retain its value over the long term.

\section{Theme: Technological developments}

- Remote conferencing technology makes it unnecessary to fly to often remote places for meetings. However, onboard technology facilitates on-board meetings and the management of operations, thus increasing the demand for business aircraft.

\section{Theme: Supporting infrastructure}

- South Africa has excellent aviation infrastructure and maintenance facilities, which is often a major challenge in the rest of the Africa

\section{Theme: Business aircraft market dynamics}

- The type of aircraft utilised the most in South Africa are turboprops, but helicopters are gaining in popularity.

- The most popular utilisation models are direct ownership, chartering, followed by fractional ownership at a lesser extent.

These themes raised by the business aircraft industry experts were incorporated into the questionnaire used in the survey.

\section{Results: Second phase}

The survey was conducted during the second phase of the research.

\section{Firmographic profile of the survey respondents}

The 30 respondents were active in the following economic sectors: Financial $(43 \%)$, Basic Materials (33\%), Consumer Services (7\%), Consumer Goods (7\%), Industrials (3\%), Telecommunications (3\%) and Health Care (3\%) sectors. By number of employees, $87 \%$ of the responding companies had more than 5000 employees, while $57 \%$ had more than 10000 employees. By market capitalisation figures, all 30 respondents had a market capitalisation of more than R50 billion, and 49\% had a market capitalisation of more than R100bn. While $76 \%$ of the responding companies had an annual revenue of greater than R20bn, 50\% had an annual revenue greater than $\mathrm{R} 60 \mathrm{bn}$. These were large corporates who were expected to be users of business aircraft.

\section{Extent of demand for business aircraft}

Of the 30 respondents, 11 were current users of business aircraft, while 19 did not utilise business aircraft. Whether or not the business aircraft users would consider increasing utilisation of business aircraft in the future, six companies affirmed that they would be interested, two would definitely increase their utilisation of business aircraft in the future, while two would not consider it and one did not respond.

Of the current 19 non-users of business aircraft, 14 would not consider utilising business aircraft in the future, while 5 companies indicated that they might consider utilising business aircraft in the future.

\section{Aviation requirements of companies in need of business aircraft}

Specific aviation requirements were explored in terms of the preferred utilisation model and aircraft type of current business aircraft users (multiple responses were allowed to indicate company preferences.). Direct ownership (7) seemed to be the most preferred utilisation model, followed by charter services (5), flight cards (4), leasing (1) and fractional ownership (1). Regarding the choice of aircraft type, helicopters (7) are preferred, followed by light single or twin piston aircraft (5), turboprops (4) and jets (4).

\section{Underlying factors that drive the demand for business aviation}

The underlying factors were explored in terms of the operational reasons for utilisation, the benefits, the deterrents and the negative factors affecting utilisation. For the 11 current users, the major reasons for the demand for business aircraft (Figure 1) seem to be access to dispersed (8 respondents), remote (7 respondents) and multiple (7 respondents) geographic locations, followed by emergency travel needs ( 6 respondents) and destinations not serviced by commercial airlines (5).

In terms of the attitude of potential and existing users towards the perceived benefits of business aircraft, of the 18 benefit options listed (Figure 2), 6 benefits resonated most (agreed and strongly agreed) with the 30 respondents: access to remote areas (93\%), timetable flexibility compared to

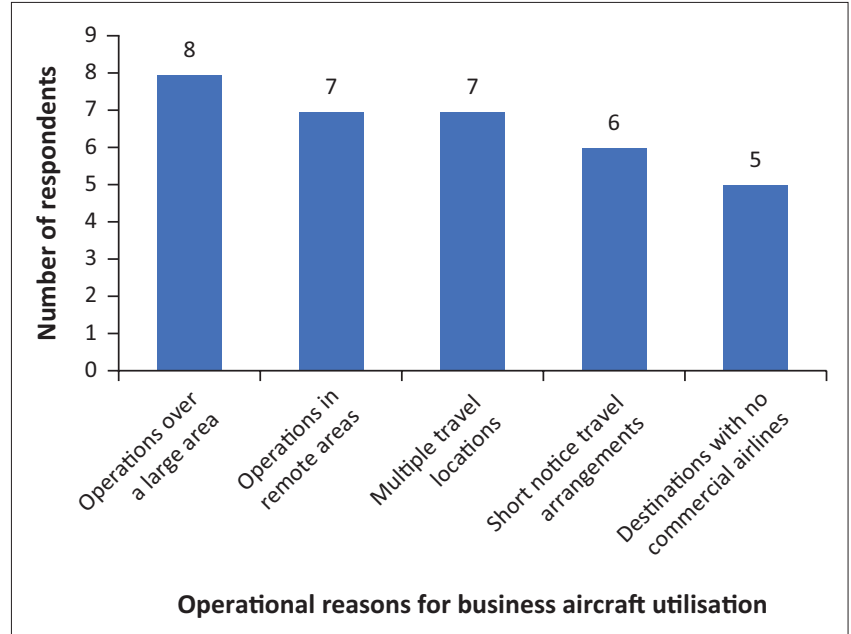

FIGURE 1: Operational reasons for utilising business aircraft $(n=11)$. 


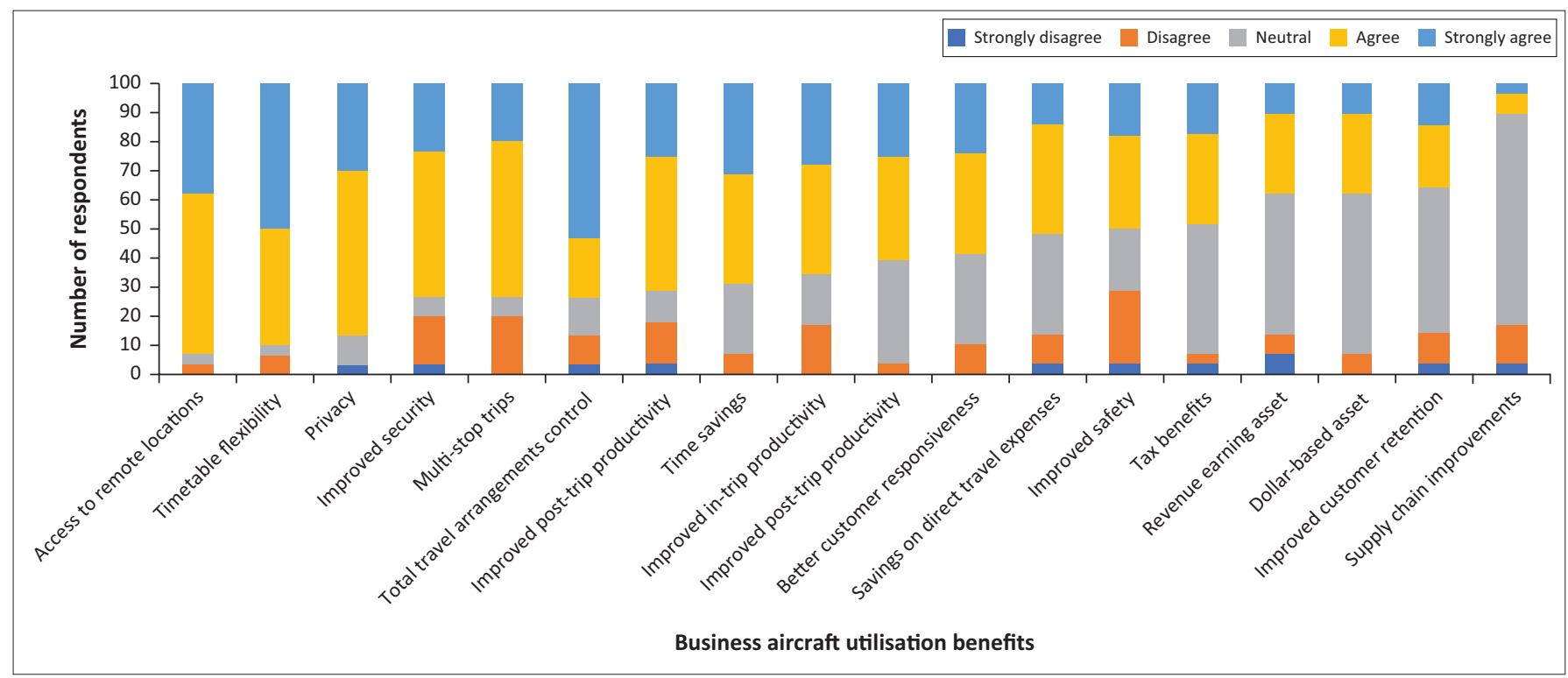

FIGURE 2: Benefits of utilising business aircraft $(n=30)$.

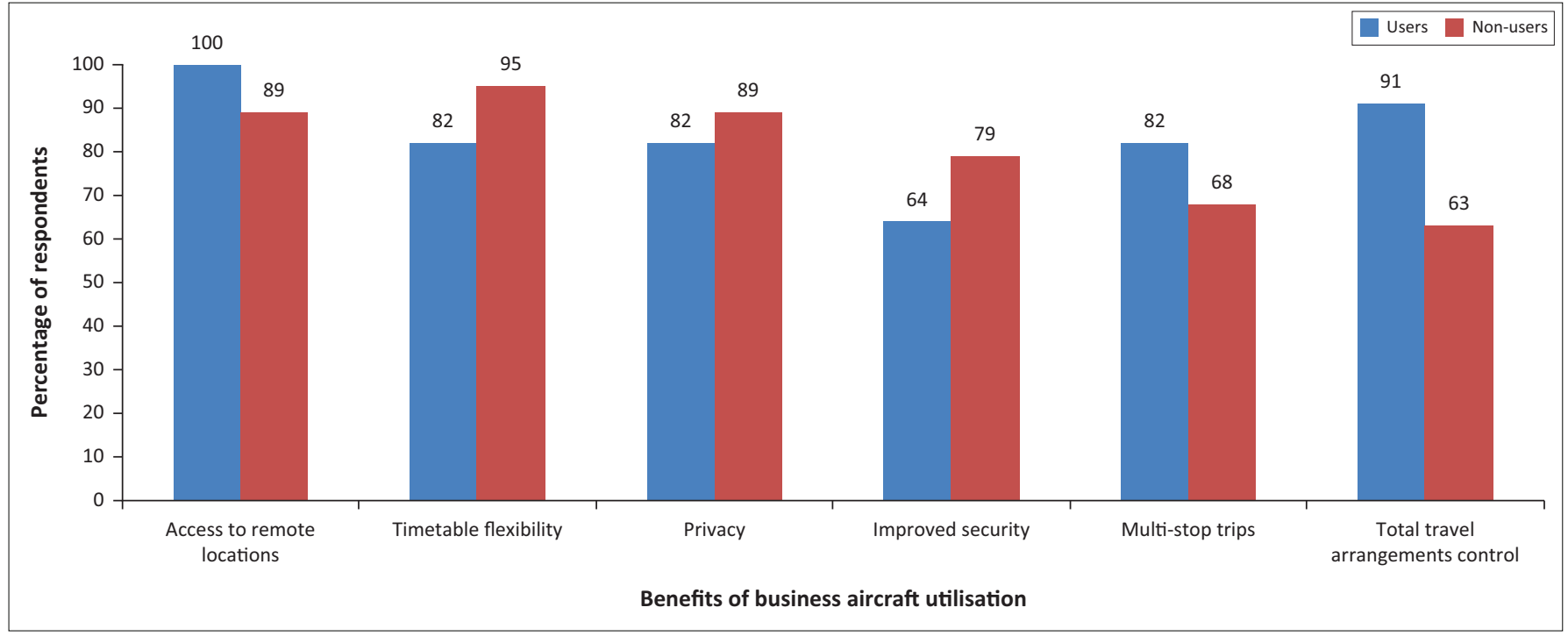

FIGURE 3: Comparison of business aircraft users and non-users regarding benefits of utilisation ( $n=11$ users and $n=19$ non-users).

commercial aircraft $(90 \%)$, privacy $(87 \%)$, total control over travel arrangements $(73 \%)$, improved security for senior personnel $(73 \%)$ and flexibility of making a trip involving stops at several locations $(73 \%)$.

Of the 11 listed possible deterrents for utilising business aircraft, the 30 respondents agreed and strongly agreed mostly with the cost-related factors: operating costs (other overheads) (97\%), operating costs (maintenance) (90\%), management costs $(86 \%)$, cost of staffing $(86 \%)$, expensive utilisation in economic downturns (86\%) and aircraft underutilisation (86\%). However, $80 \%$ indicated that 'negative stakeholder perceptions' is a deterring factor.

Similar results were found when assessing the 15 factors that would negatively impact on business aircraft utilisation. The 30 respondents agreed and mostly agreed with: operating costs (93\%), maintenance costs $(93 \%)$, poor economic conditions (90\%), stakeholder perceptions (90\%), capital costs $(86 \%)$ and limited aviation knowledge (81\%).

\section{Differences between users and non-users}

Regarding the six listed benefits of business aircrafts, all the users perceived the primary benefit to be 'access to remote locations', while most non-users (95\%) perceived 'timetable flexibility' to be the primary benefit (Figure 3).

Regarding the top six factors perceived as deterrents to the usage of business aircraft, the users were mostly deterred by the maintenance cost (90\%). All the non-users were deterred by most of the listed deterrents (Figure 4). This is indicative that perception adjustment of non-users could be an important marketing strategy to become potential users.

Of the six factors deemed to have a negative effect on business aircraft utilisation, both the users and non-users 


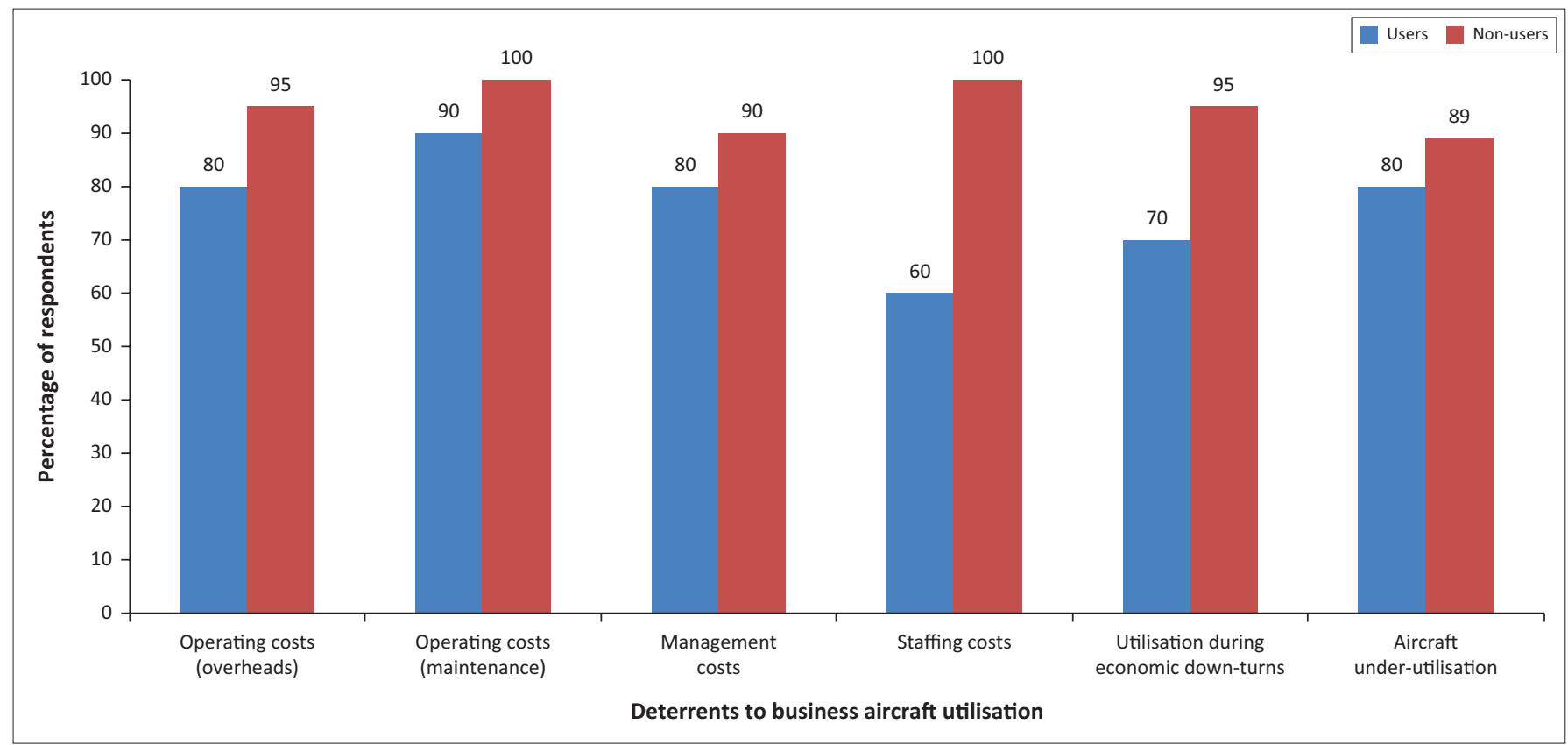

FIGURE 4: Comparison of business aircraft users and non-users regarding deterrents to utilisation ( $n=11$ users; $n=19$ non-users).

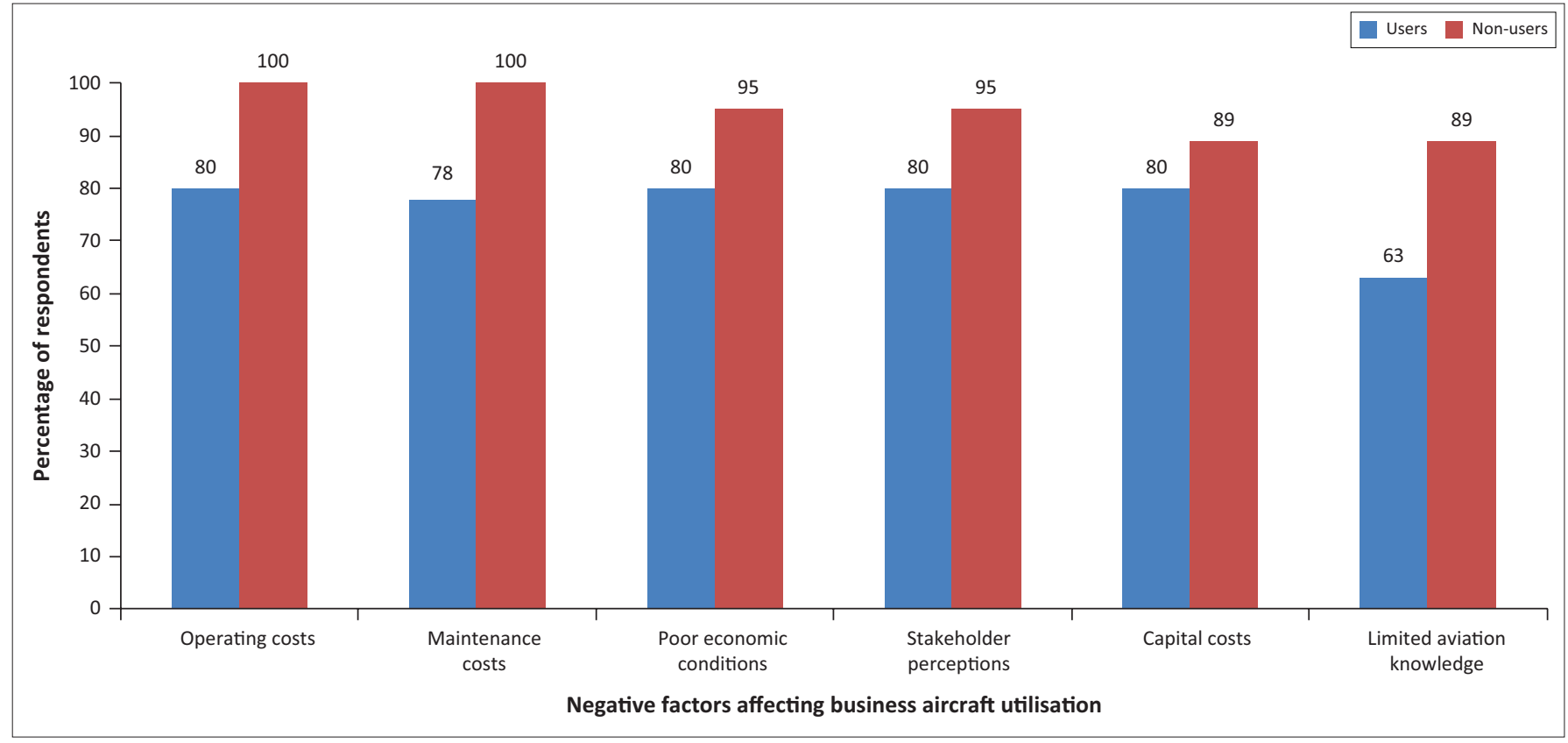

FIGURE 5: Comparison of business aircraft users and non-users regarding negative factors which affect utilisation ( $n=11$ users; $n=19$ non-users).

were concerned with the four cost-related factors, namely operating costs, maintenance costs, poor economic conditions and capital costs, but the non-users much more so than the users (Figure 5). It follows that 'limited aviation knowledge' has a much greater negative effect on nonusers than users, probably because of the limited experience of non-users.

\section{Discussion}

\section{Extent of demand for business aircraft}

The results indicate that growth in the market for business aircraft is likely to come from existing users. Only a small fraction of the non-current users is likely to consider utilisation in the future, and the majority of non-users are adamant that they will not utilise business aviation in the near future.

\section{Aviation requirements of companies in need of business aircraft}

The findings for most popular models for utilising business aircraft, being direct ownership and charter services, were in-line with the findings from the qualitative research. The findings for helicopters as the most preferred type of aircraft were however different to the qualitative research findings and may thus require further research with a more representative sample. 


\section{Underlying factors that drive the demand of business aviation}

The major drivers of the demand for business aircraft were related to access to geographical locations and, to a lesser extent, the need to travel to multiple locations within a short period of time. The top three results in terms of the benefits of business aircraft utilisation reinforce the need to utilise business aircraft to travel to far-flung and remote areas not serviced by commercial airlines, along with flexibility to travel at short notice. These are the key determinants of the demand for business aircraft.

According to the perceptions of the respondents, the major drawback of operating business aircraft (users and nonusers) are the costs associated with the aircraft (operating, management, staffing and overheads). Other key deterring factors are aircraft utilisation during economic downturns and the under-utilisation of the aircraft.

\section{Differences between perceptions of users and non-users}

Although both users and non-users perceived a business aircraft as a beneficial mode of travel, marked differences in the way they viewed the individual driving factors existed. Users generally rated the benefit factors higher than the nonusers. Non-users, on the contrary, rated the negative factors such as costs higher than the users. These differences in perception seem to point to differences in lived and perceived experiences and thus present opportunities for business aircraft companies to embark on education drives for nonusers in order to attract them.

\section{Conclusion}

Following from the results and discussion, concrete, practical and actionable recommendations and strategies towards growth in the business aircraft market are presented next.

Strategy 1 - Cost-benefit analysis case studies: Business aircraft companies are encouraged to develop cost-benefit analysis (CBA) models based on case studies of current users in order to attract non-users. A CBA should calculate the net benefit figure for the utilisation of business aircraft by subtracting the sum of direct and indirect costs from the sum of direct and indirect benefits (Willems 2006). These CBA models will be used to demonstrate to current non-users that the benefit value of a business aircraft can outweigh the costs over its lifecycle.

Strategy 2 - Business-aviation needs profile: Business aviation companies are encouraged to develop information profiles through firmographic profiles of current users and the business aircraft utilisation methods they typically choose. These profiles can then be used to match the needs of potential users to suitable business aircraft products based on similar current users.

Strategy 3 - Typical user firmographic profiles: Business aviation companies can develop user profiles of current users and then use these to target current non-users who match the profile.

Strategy 4 - Business aviation turnkey service: Some of the learnings identified from the study findings indicate the need for a dedicated turnkey service that can manage onerous, time-consuming and complex matters on behalf of existing and potential users of business aircraft. The envisaged turnkey services should provide an advisory service on regulatory requirements, a tax advisory service, a revenue creation service through leasing to third-parties, an origination service for capital and insurance, and finally, a general advisory service on aviation matters.

Strategy 5 - Stakeholder management: In order to counter the misconception of business aircraft by stakeholders, business aviation companies are recommended to engage in case studies of companies that utilise business aircraft and have successfully managed to overcome these negative perceptions.

The strategies are linked to the research findings (Table 1), succinctly highlighting these findings while juxtaposing them against pragmatic strategies to grow the business aircraft market, as recommended.

From the results, it is concluded that the potential future growth for the business aircraft market is most likely to come from existing users, while only marginal growth could be expected from new entrants (current non-users) in the market. However, this conclusion is mitigated by the small response rate as well as the limitations of the research sample. Therefore, it is not feasible to draw definitive conclusions

TABLE 1: Strategies to grow the business aviation industry.

\begin{tabular}{|c|c|c|c|c|}
\hline No. & Findings & Cross-cutting to both users and non-users & Specific to users & Specific to non-users \\
\hline 1 & $\begin{array}{l}\text { Potential users are struggling to match business aviation offerings with their } \\
\text { organisational needs }\end{array}$ & Strategy 2 & Strategy 2 & Strategy 4 \\
\hline 2 & Business aircraft utilisation is directly linked to an organisation's firmographic profile & - & Strategy 3 & - \\
\hline 4 & $\begin{array}{l}\text { A business aircraft's operational, management and regulatory costs are a deterring } \\
\text { factor for utilisation }\end{array}$ & - & - & - \\
\hline 5 & Periods of economic downturn negatively affect the utilisation of business aircraft & Strategy 1 & - & Strategy 4 \\
\hline 6 & $\begin{array}{l}\text { Stakeholders have a negative perception of a business aircraft as a value-generating } \\
\text { asset }\end{array}$ & - & - & Strategy 5 \\
\hline 7 & The regulator has a negative impact on the utilisation of business aircraft & - & - & Strategy 4 \\
\hline
\end{tabular}


regarding the extent of the demand for business aircraft in South Africa.

The major limitation is that the scope of the study was restricted to the top 100 JSE-listed companies, based on the premise that they are highly likely to use business aircraft. Thus, many companies that are not listed, such as small and medium enterprises, public institutions and private high-net worth individuals from which demand could arise, were excluded.

Future research should substantially expand the target population to include companies that are not listed, such as small and medium enterprises, public institutions and private high-net worth individuals from which demand could arise. In addition, the potential of charter and flight card services should be explored.

\section{Acknowledgements}

The authors wish to acknowledge the assistance of Mr. Piet van Hoven, the Chairperson of Comair Ltd, for his valuable guidance in this research project.

\section{Competing interests}

The authors declare that they have no financial or personal relationships that may have inappropriately influenced them in writing this article.

\section{Authors' contributions}

All the authors made a substantial contribution to the conception and design of the multi-disciplinary project. M.J.M., N.J.M. and B.T. did the literature review, and collected and analysed data. All the authors were involved in the interpretation of data. M.J.M., N.J.M. and B.T. drafted the manuscript, and J.W., M.A.M. and E.S. critically revised it for important intellectual content and approved the final version to be published.

\section{Funding information}

This research received no specific grant from any funding agency in the public, commercial or not-for-profit sectors.

\section{Data availability statement}

Data sharing is not applicable to this article as no new data were created or analysed in this study.

\section{Disclaimer}

The views expressed in this article are the authors' own and do not reflect an official position of the University of Johannesburg.

\section{References}

Andersen, P., McNay, D. \& Peterson, J., 2012, Business jet aircraft industry: Structure and factors affecting competitiveness, U.S. International Trade Commission, Washington, DC

AfBAA, 2015, The state of business aviation in Africa and the 2020 road-map for AfBAA, viewed 18 August 2016, from http://AFBAA.org/system/publications/ assets/000/000/004/original/AFBAA - State_of Business_Aviation_in_Africa. pdf?1431717438.

Bombardier, 2016, Market forecast 2016-2025, viewed 04 June 2017, from http:// ir.bombardier.com/var/data/gallery/document/85/38/92/64/14/BombardierBusiness-Aircraft-2016-2025-Market-Forecast-en.pdf.

Civil Aviation Authority (CAA), 2017, Airports: About aerodromes and facilities, viewed 27 May 2017, from http://www.caa.co.za/Pages/Airports/About-Aerodromesand-Facilities-.aspx.

Deloitte, 2014, Private aircraft: Flying private makes sense for those with the right information, viewed 18 August 2016, from http://www2.deloitte.com/ content/dam/Deloitte/us/Documents/Tax/us-tax-deloitte-private-aircraft022615.pdf.

GAMA, 2016, General aviation statistical databook \& industry outlook, viewed 16 May 2017, from https://gama.aero/wp-content/uploads/2016-GAMA-Databook forWeb.pdf/.

Harris Interactive, 2009, The real world of business aviation: A survey of companies using general aviation aircraft, viewed 19 August 2016, from https://www.nbaa. $\mathrm{org} /$ business-aviation/Real-World-of-Business-Aviation-2009.pdf.

ICAO, 1998, Economic contribution of civil aviation: Ripples of prosperity, viewed 19 August 2016, from http://www.icao.int/sustainability/Documents/ EconContribution.pdf.

IMF, 2017, World economic outlook October 2017, viewed 22 March 2018, from https://www.imf.org/ /media/Files/Publications/WEO/2017/October/pdf/.

NEXA, 2009, Business aircraft: An enterprise value perspective, viewed 27 April 2016 from http://www.nbaa.org/business-aviation/NEXA-Report-Part-1-2009.pdf/.

Saunders, M., Lewis, P. \& Thornhill, A., 2012, Research methods for business students, 6th edn., Pearson, Harlow, Essex, UK.

Statistics South Africa, 2017, Gross domestic product: First quarter 2017 viewed 04 June 2017, from http://www.statssa.gov.za/publications/P0441/ P04411stQuarter2017.pdf.

SustainAvia Research and Certification, 2012, Direct operating costs of busines aircraft - Business aviation for a sustainable economy (BASE) [Online], viewed 17 September 2016, from http://www.sustainavia.com/documents/130/cleanskybase-t4.2-final.pdf

The World Wealth Report, 2018, The world wealth report 2018, viewed 04 April 2018, from www.knightfrank.com/resources/wealthreport2018/the-wealthreport-2018.pdf

Willems, J., 2006, Commercial business aviation: A valuable travel alternative for business companies in Germany?, Bonn - International University of Applied Sciences Bad Honnef, Bad Honnef, Germany. 